\title{
Optimization of accurate estimation of single diode solar photovoltaic parameters and extraction of maximum power point under different conditions
}

\begin{abstract}
Introduction. With the snowballing requirement of renewable resources of energy, solar energy has been an area of key concern to the increasing demand for electricity. Solar photovoltaic has gotten a considerable amount of consideration from researchers in recent years. Purpose. For generating nearly realistic curves for the solar cell model it is needed to estimate unknown parameters with utmost precision. The five unknown parameters include diode-ideality factor, shunt-resistance, photon-current, diode dark saturation current, and series-resistance. Novelty. The proposed research method hybridizes flower pollination algorithm with least square method to better estimate the unknown parameters, and produce more realistic curves. Methodology. The proposed method shows many promising results that are more realistic in nature, as compared to other methods. Shunt-resistance and series-resistance are considered and diode constant is not neglected in this approach that previously has been in practice. The values of series-resistance and diode-ideality factor are found using flower pollination algorithm while shunt-resistance, diode dark saturation current and photon-current are found through least square method. Results. The combination of these techniques has achieved better results compared to other techniques. The simulation studies are carried on MATLAB/Simulink. References 34, tables 5, figures 10.
\end{abstract}

Key words: maximum power point, maximum power point error, genetic algorithm, flower pollination algorithm.

Bступ. 3 огляду на величезну потребу у відновлюваних енергетичних ресурсах, сонячна енергія стала ключовою сферою розв'язання проблеми зростання попиту на електроенергію. За останні роки сонячна фотоелектрична техніка отримала значну увагу з боку дослідників. Мета. Для створення майже реалістичних кривих для моделі сонячних батарей необхідно очінити невідомі параметри з максимальною точністю. П'ять невідомих параметрів включають коефічієнт ідеальності діодів, опір шунту, фотонний струм, струм темного насичення діодів і послідовний опір. Новизна. Запропонований метод дослідження поєднує алгоритм запилення квітів із методом найменших квадратів для кращої очінки невідомих параметрів та отримання більш реалістичних кривих. Методологія. Запропонований метод демонструє багато перспективних результатів, які є більш реалістичними за своєю природою, порівняно з іншими методами. Розглянуто опір шунта $i$ послідовний опір, $і$ в иьому підході, який раніше застосовувався на практиці, не нехтують постійною діода. Значення послідовного опору та коефіцієнта ідеальності діодів визначаються за допомогою алгоритму запилення квіток, тоді як опір шунту, струм темного насичення діодів і фотонний струм - методом найменших квадратів. Результати. Поєднання uих методів забезпечило кращі результати у порівнянні з іншили методами. Моделювання проводиться на MATLAB/Simulink. Бібл. 34, табл. 5, рис. 10.

Ключові слова: максимальна точка потужності, максимальна похибка точки потужності, генетичний алгоритм, алгоритм запилення квіток.

1. Introduction. Electrical energy demand is increasing day by day due to high consumption by industries and competition among industrial community [1]. Also the electrical faults and interconnected power system make the cost and emission ratio very high $[2,3]$. To meet the need of good quality electrical energy, the research interest in solar cell have increased considerably to increase the application of solar power [4]. A large amount of time and money has been invested to accurately estimate the unknown parameters of solar cell [5]. There are various methods to accurately estimate parameters i.e., analytical, numerical and meta-heuristic methods. In $[6,7]$ an analytical method is proposed that relies on the correct placement of the data for the exact estimation of parameters. So to better optimize and control the photovoltaic (PV) systems it is imperative to simulate the P-V characteristics before the installation of the solar panel $[4,5]$. This data is collected from the datasheet and characteristic curve of solar cell. Despite having a number of benefits like accuracy and less computational time these methods have some demerits as well i.e., in case if number of unknown parameters are large one can expect errors in result [8] and a higher computational time is also required. While in numerical methods, in contrast to analytical, every sample point from the characteristic curve of the solar cell is considered. This method generates better results as compared to the analytical methods $[8,9]$. The numerical-methods, i.e., Gauss Seidel $[6,10]$ and Newton-Raphson $[11,12]$ have been in frequent use by researchers for the estimation of solar cell parameters. Although the accuracy of numerical methods is high but their dependence on accurate initial guesses has been found very difficult in case of larger number of unknowns $[13,14]$. That can cause a solution to converge to local-minima rather than a global-minima. So, it is necessary to solve current optimization challenges [15-17] to sort out issues in numerical and analytical techniques. Many meta-heuristic techniques have been proposed which are genetic algorithm (GA) [18], particle swarm optimization (PSO) algorithm $[19,20]$, simulated annealing (SA) [21], differential algorithm (DA) [22], and teaching learning algorithm (TLA) [23].

Aforementioned techniques have been proved to be more efficient in estimating the unknown parameters of solar cell, as compared to the numerical and analytical techniques, but these techniques were slow-convergent and sometimes unable to track accurate characteristics $[8,9]$. Computational time got considerably reduced in some of these research works either by ignoring shunt resistance $R_{s h}[24,25]$, series resistance $R_{s}[26,27]$ or by presuming the ideality factor $n$ of the diode [8]. These efforts lead to a less-accurate estimation of maximum power point error (MPPE) $[14,28]$. To enhance the

(C) F. Akbar, T. Mehmood, K. Sadiq, M.F. Ullah 
accuracy, this research works takes in account all the five electrical model parameters.

Aims and goals. The research work has following contributions:

1. Series resistance $R_{s}$ and ideality factor $V_{d i}$ are estimated using flower pollination algorithm (FPA).

2 . The other 3 remaining parameters, namely shunt resistance $R_{s h}$, photon current $I_{p h n}$, and saturation current $I_{d}$ are estimated using the least square (LS) method. The LS method helps to improve the FPA.

3. Two different PV cells are opted and used to examine the performance of the proposed method. Performance parameters such as maximum power point (MPP), MPPE and P-V characteristics curve are checked compared with the existing and proposed method to prove the effectiveness of proposed method.

The research paper is organized in sections and the detail is as: Section 2 encompasses the work done related to this topic which is already published. Section 3 presents the mathematical modelling and objective function derivation of single-diode cell model. Section 4 contains explanation of proposed technique. In section 5, the results and discussions about application of technique on different solar cells will be presented and a comparison will be made with different works already published. Section 6 presents the conclusion.

Literature review. From 2006 to 2016, the PV installations across the globe are increased from $7 \mathrm{GW}$ to $300 \mathrm{GW}$. The foremost reason for large upsurge in the installations of PV systems is an increase in costs by the amount of 2.5 to 3.5 times. The elementary code for the PV systems is to seizure light of sun with a PV module and convert it direct into electrical energy. The output for a PV module, is dependent on the climatical circumstances i.e., temperature and irradiance, is denoted with a single-diode-model [14].

The model of single-diode imitates extremely precise yield characteristics of diverse types of PV cells and modules for any type climatic circumstances. For the analysis of PV systems, it is frequently favored over the contemporaries' ones because of it having fewer parameters and fewer complexities in computations

$$
I=I_{L}-I_{0} \cdot\left(e^{\frac{q \cdot\left(V+I \cdot R_{S}\right)}{n \cdot K \cdot T}}-1\right)-\frac{V+I \cdot R_{S}}{R_{s h}},
$$

where $I_{L}$ is the current generated by light; $I_{0}$ is the reverse saturation current; $q$ is the elementary charge $\left(1.602 \cdot 10^{-19} \mathrm{C}\right)$; $V$ is the voltage; $n$ is the ideality factor of the diode; $K$ is the Boltzmann constant $\left(1.38 \cdot 10^{-23} \mathrm{~J} / \mathrm{K}\right) ; T$ is the temperature; $R_{s}$ is the series resistance; $R_{s h}$ is the shunt resistance.

The 5 factors to be defined are: $I_{L}, I_{0}, R_{s}, R_{s h}$ and $n$. In equation (1) $I$ is an understood function, such that $I=f(V, I)$. Therefore, the precise analytic explanation for $I$ is not feasible and the solution is taken with the help of iterative methods, i.e., Gauss-Seidel and NewtonRaphson. To devise $I=f(V)$ and to alleviate the process of solution, numerous explicit expressions of analytical methods occur in the published work. They employ calculations for example polynomial, Taylor series, Padé, and Chebyshev. For the single diode model, the 5 undetermined parameters determine functionality of a PV module in any climatic circumstances. Two approaches exist to discover the parameters:

1) with investigational information;

2) from the key-power points stated in the manufacturer's datasheet.

The highlights in the datasheet has problem that they can only devise 4 equations alongside 5 parameters to be resolved. To ease the problem, a discrete $n$ value is supposed to resolve the 4 equations, but the parameters acquired may not be appropriate. To design $5^{\text {th }}$ equation, De Soto [29] utilized the open-circuit situation at a temperature which is not according to the standard test conditions. Although, the final explanation's vulnerable to a selected range of a temperature. An enhanced $5^{\text {th }}$ equation is developed that correlates $n$ and the open circuit voltage $\left(V_{o c}\right)$. The slope $\mathrm{d} I / \mathrm{d} V$ at short circuit condition is believed to be $5^{\text {th }}$ equation that is equivalent to negative inverse of $R_{s h}$, but it is only valid if $R_{s h}>>R_{s}$ and is mainly applicable for modules of silicon and it might flunk for solar cells of thin-film solar. Consequently, the dilemma is there to choose the $5^{\text {th }}$ equation that achieves the process of solution. This research presents technique that approximate the 5 unknown parameters of the single-diode model is produced. Highlight of the method is that the design of the $5^{\text {th }}$ equation uses an accurate area under the $I-V$ curve with other 4 equations derived from datasheet values. The recommended technique deems an $I-V$ set of data of a PV cell/module as it requires the area under the curve. This technique also demonstrates an approach for pondering for 5 parameters' initial guesses. The recommended technique gets applied to earlier state few cells like copper indium gallium selenide, silicon, dye-sensitized and perovskite.

2. Related works. Many research works have been published which propose different methods to extract unknown parameters of solar cells. All the methods have advantages and merits related to it but they also have some demerits.

2.1. Numerical methods. The numerical methods are still in use, but they still depend on initial guesses for accuracy. If initial guesses are wrong, the solution gets converged to local minima that is a disadvantage. Gauss Seidel [6, 10] and Newton-Raphson [11, 12] are the examples of some numerical methods.

2.2. Meta-heuristic methods. Meta-heuristic techniques are mostly inspired by nature optimization problems which give accurate and close to real optimization results with very small uncertainty possibilities. Even with slightly wrong initial guesses they give accurate results. They are more likely to make solution convergence at global optima, but these methods can cause the convergence time to be long and iteration to be large making it a little unfeasible. GA [18], PSO [19], [20], SA [21], DA [22], and TLA [23] are some metaheuristic algorithms.

It is concluded from above discussion that every technique possesses some merits and demerits related to it that doesn't make it to be a perfect choice for parameter estimation. The proposed technique hybridized both 
numerical and meta-heuristic methods to devise a new reliable and effective method.

3. Mathematical modelling of solar cell and objective function. Simplicity and accuracy of single diode model makes it a good choice for considering it to use for parameter estimation [30, 31], and is shown in Fig. 1, in which $R_{s}$ represents the bulk and metal contact resistance, $R_{s h}$ represents electron holes pairs recombination, $I_{d}$ is the diode dark saturation current, $I_{o}$ is output current, $I_{p h n}$ is photon current and $V_{L}$ is output voltage.

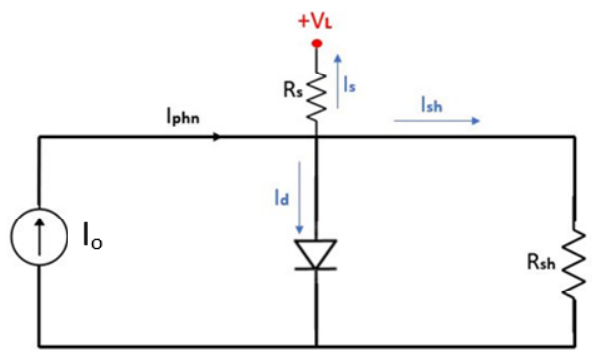

Fig. 1. Electrical circuit diagram for single diode model equation:

The relationship between $I_{o}$ and $V_{L}$ is given in next

$$
I_{o}=I_{p h n}-I_{d} \cdot\left(e^{\left(\frac{V_{L}+I_{o} \cdot R_{S}}{V_{d i}}\right)}-1\right)-\frac{V_{L}+I_{o} \cdot R_{S}}{R_{S h}},
$$

where $V_{d i}$ is the diode internal voltage:

$$
V_{d i}=\frac{n \cdot K \cdot T \cdot S_{c S}}{q},
$$

where $S_{c s}$ is the number of cells connected in series.

The parameters that aren't stated in manufacturer datasheet and are yet to be determined are: $I_{p h n}, I_{d}, R_{s}, R_{s h}$, and $V_{d i}$. It is evident from (1), (2) that the characteristic curve relies on unknown parameters stated earlier. So, precise and accurate estimation of these unknown parameters is imperative.

So, the necessary set of equations that are needed for estimating undetermined parameters are following:

1. $I_{S}$ is obtained by putting load voltage $V_{L}=0$ in Eq. (1) and making a short circuit at the load

$$
I_{o}=I_{p h n}-I_{d} \cdot\left(e^{\left(\frac{I_{s} \cdot R_{s}}{V_{d i}}\right)}-1\right)-\frac{I_{s} \cdot R_{s}}{R_{s h}} .
$$

2. Following equation is obtained by putting $I_{o}=0$ in Eq. (1) and open circuiting the load terminal of the solar PV

$$
I_{p h n}-I_{d} \cdot\left(e^{\left(\frac{V_{o c}}{V_{d i}}\right)}-1\right)-\frac{V_{o c}}{R_{s h}}=0
$$

3. By putting maximum power point voltage $V_{m p}$ and maximum power point current $I_{m p}$ in (1):

$$
I_{m p p}=I_{p h n}-I_{d} \cdot\left(e^{\left(\frac{V_{m p p}+I_{m p p} \cdot R_{s}}{V_{d i}}\right)}-1\right)-\frac{V_{m p p}+I_{m p p} \cdot R_{s}}{R_{s h}}
$$

4. $P-V$ curve at MPP is obtained by drawing a tangent parallel to the voltage axis

$$
\mathrm{d} P / \mathrm{d} v_{m p p}=0
$$

After solving (6) we have:

$$
\mathrm{d} I_{o} / \mathrm{d} V_{L m p p}=-I_{m p p} / V_{m p p} .
$$

Using Eq. (1) and (7), the following final equation is obtained:

$$
I_{m p p}=\left(V_{m p p}-I_{m p p} \cdot R_{s}\right) \cdot\left(\frac{I_{d}}{V_{d i}} \cdot e^{\left(\frac{V_{m p p}+I_{m p p} \cdot R_{s}}{V_{d i}}\right)}-\frac{1}{R_{s h}}\right)=0 .
$$

5. At short circuit condition, the obtained slope:

$$
\mathrm{d} I_{o} / \mathrm{d} V_{L I-I_{s}}=-1 / R_{s h} .
$$

6. By solving Eq. (9):

$$
\frac{I_{d}}{V_{d i}} \cdot e^{\left(\frac{I_{s} \cdot R_{s}}{V_{d i}}\right)} \cdot\left(R_{s h}-R_{s}\right)=\frac{R_{S}}{R_{s h}} .
$$

So, (3), (4), (5), (8), and (10) are needed for estimating 5 unknown parameters.

The $R_{s}$ and $V_{d i}$ will be used to derive the characteristic equation for solar P-V curve. FPA is applied on characteristic equation to estimate the 2 unknowns $\left(R_{s}\right.$ and $\left.V_{d i}\right)$. Since characteristic equation depends on 2 parameters only so it makes solutions to convergence faster and accurate.

Following are the steps to derive the proposed characteristics equation.

The value of $I_{p h n}$ is taken from Eq. (4) and is substituted in (3), (5) to get the expression for $I_{s}$ and $I_{m p}$, as follows:

$$
\begin{gathered}
I_{s}=(y-x) \cdot I_{d}+\frac{V_{o c}-I_{s} \cdot R_{s}}{R_{s h}} ; \\
I_{m p p}=(y-z) \cdot I_{o}+\frac{V_{o c}-V_{m p p}-I_{m p p} \cdot R_{s}}{R_{s h}} ;
\end{gathered}
$$

where:

$$
x=e^{\left(\frac{I_{s c} \cdot R_{s}}{V_{d i}}\right)}-1 ; y=e^{\left(\frac{V_{o c}}{V_{d i}}\right)}-1 ; z=e^{\left(\frac{V_{m p p}+I_{m p p} \cdot R_{s}}{V_{d i}}\right)}-1 .
$$

To find expressions for $I_{s}$ and $I_{m p}$ in terms of $R_{s}, R_{s h}$ and $V_{d i}$, the value of $I_{o}$ is taken from Eq. (10) and is substituted in (8), (11), (12) which gives:

$$
\begin{gathered}
I_{s}=\frac{(y-x) \cdot V_{d i} \cdot R_{s}}{R_{s h} \cdot(1+x) \cdot\left(R_{s h}-R_{s}\right)}+\frac{V_{o c}-I_{s} \cdot R_{s}}{R_{s h}} ; \\
I_{m p p}=\frac{(y-z) \cdot V_{d i} \cdot R_{s}}{R_{s h} \cdot(1+x) \cdot\left(R_{s h}-R_{s}\right)}+\frac{V_{o c}-V_{m p p}-I_{m p p} \cdot R_{s}}{R_{s h}} \\
I_{m p p}=\left(V_{m p p}-I_{m p p} \cdot R_{s}\right) \cdot\left(\frac{R_{s}+(1+z)}{R_{s h} \cdot(1+x) \cdot\left(R_{s h}-R_{s}\right)}+\frac{1}{R_{s h}}\right) ;
\end{gathered}
$$

Equations (14), (15) are equated to get $R_{s h}$ :

$$
\begin{aligned}
& R_{s h}=R_{s}+\left(\frac{R_{S}}{2 \cdot V_{m p p}-V_{o c}}\right) \times \\
& \times\left(\frac{V_{d i} \cdot(y-z)-(1+z) \cdot\left(V_{m p p}-I_{m p p} \cdot R_{S}\right)}{1+x}\right) ;
\end{aligned}
$$


The $R_{s h}$ can also be derived (13), (14) as follows: $R_{s h}=\frac{V_{o c} \cdot(x-z)+I_{s} \cdot R_{s} \cdot(z-y)+\left(V_{m p p}+I_{m p p} \cdot R_{s}\right) \cdot(y-x)}{I_{s c} \cdot(y-z)+I_{m p p} \cdot(x-y)}$
The proposed equation is derived by using Eq. (16) and (17), as follows:

$$
f\left(R_{s}, V_{d i}\right)=\left[R_{s}+\frac{R_{s}}{2 \cdot V_{m p p}-V_{o c}} \cdot\left(\frac{V_{d i} \cdot(y-z)}{1+x}\right)-\left(\frac{-(1+z) \cdot\left(V_{m p p}-I_{m p p} \cdot R_{s}\right)}{1+x}\right)\right]-R_{s h}=0 .
$$

So, (18) can only be used to estimate the values of $R_{s}$ and $V_{d i}$. This model has only 2 unknowns instead 5 that makes it converge at a faster rate and generate accurate results. Equation (18) is a non-linear singleobjective optimization function, and FPA is used to minimize it. The edge of this thing is that computation time is reduced number of equations required (five) have been reduced to 4 for estimating 5 parameters.

4. Proposed technique. The proposed technique employs FPA and least square method to estimate 5 unknown parameters. FPA is a nature inspired metaheuristic optimization algorithm, and least square is a numerical method. Both the methods are briefly explained below and depicted in Fig. 2.

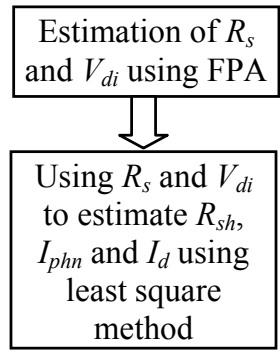

Fig. 2. Flow chart for proposed technique

4.1. Flower pollination algorithm (FPA). In 2012 Yang proposed a meta-heuristic algorithm called FPA that is inspired by the process of pollination in flowering plants [32]. This cross-pollination is considered as global pollination while self-pollination is considered as local pollination for the process of evolution. Optimization capability of FPA is very good and it also has fast convergence rate. Many research studies have proven FPA to be better than contemporaries like PSO and GA in multi-peak test functions [32].

There are 2 ways of pollination in flowering plants, one is cross pollination and other is self-pollination as shown in Fig. 3. Birds, bees and insects act as pollinators in cross-pollination that carry pollens at long distances so that they cross the gap among flowers and facilitate in pollen exchange with flowers far away. So, this heterogeneous pollination in FPA is called global pollination. The transfer of pollens with flowers around with help of pollinators i.e., air/wind is called selfpollination and it is termed as local pollination in FPA.

The decision whether pollination is going to be cross or self is being dealt by a parameter $p$ called probability switch. To make the problem easy, it's supposed that each plant possesses one flower and every flower owns only one pollen that is a possible solution to the problem.

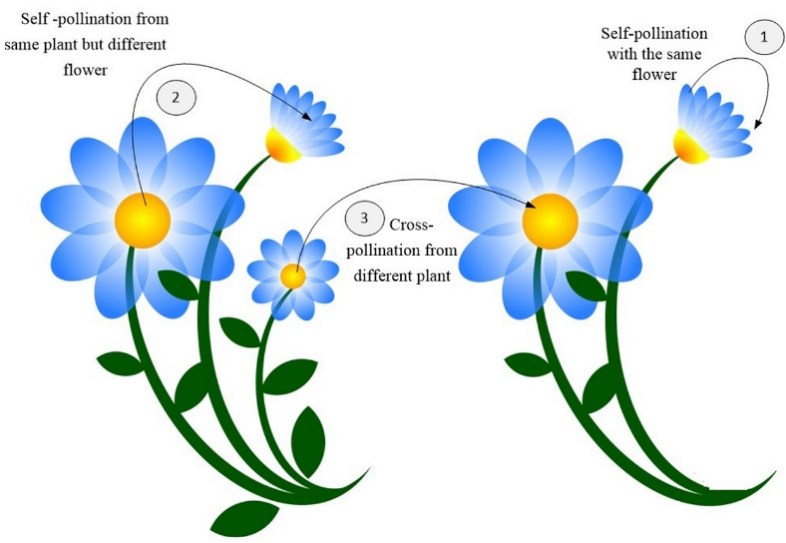

Fig. 3. Process of flower pollination

4.1.1. Global pollination. Global pollination is carried by birds or insects which follow Levy flight characteristics which means the step size for global pollination obeys Levy distribution. Global pollination is described mathematically as:

$$
X_{i}^{t+1}=X_{i}^{t}+\gamma \cdot L \cdot\left(X_{\text {best }}-X_{i}^{t}\right) ;
$$

where $X_{\text {best }}$ represents the best individual solution in the iterations happened so far; $X_{i}^{t}$ is the $t^{\text {th }}$ generation solution (current generation); $X_{i}^{t+1}$ is the $(t+1)^{\text {th }}$ generation solution (next generation); $L$ represents the intensity of global pollination that is the step size of pollen movement; $\gamma$ is a scaling factor that controls step size.

The mathematical description of Levy distribution is as follows:

$$
L=\frac{\lambda \cdot \Gamma(\lambda) \cdot \sin \left(\frac{\lambda \cdot \pi}{2}\right)}{\pi} \cdot \frac{1}{S^{1+\lambda}},\left(S>>S^{0}>0\right),
$$

where $\Gamma(\lambda)$ represents the standard gamma function; $S$ is Levy flight step size; $S^{0}$ is the minimum step size; $\lambda$ is a constant $(\lambda=1.5)$. follows:

The $S$ is generated by use of technique in [28] as

$$
\begin{gathered}
S=\frac{U}{|V|^{1 / \lambda}} ; \text { for } U \sim N\left(0, \sigma^{2}\right), V \sim N(0,1), \\
\Sigma^{2}=\frac{\Gamma(1+\lambda) \cdot \sin (\lambda \cdot \pi / 2)}{\Gamma\left[\left(\frac{1+\lambda}{2}\right)\right] \cdot \lambda \cdot 2^{\frac{\lambda-1}{2}}},
\end{gathered}
$$

where $U$ and $V$ obey the Gaussian distribution [32].

4.1.2. Local pollination. Local pollination happens between nearby plants and is done by abiotic sources like 
wind. The mathematical representation of local pollination is:

$$
X_{i}^{t+1}=X_{i}^{t}+\varepsilon \cdot\left(X_{j}^{t}-X_{k}^{t}\right), \quad \varepsilon \sim U(0,1)
$$

where $X_{i}^{t+1}$ is the single solution generated at $(t+1)^{\text {th }}$ generation; $X_{j}^{t}$ and $X_{k}^{t}$ represent the $j^{\text {th }}$ and $k^{\text {th }}$ individual solutions respectively in the $t^{\text {th }}$ generation, and $\varepsilon$ represents the local pollination coefficient which is uniformly distributed in $[0,1]$.

4.1.3. Switching probability. Among global and local pollination, the decisive factor is called switch of probability that is represented by $p$. In [32], it has been proved that when $p=0.8$, it gives good results. How $p$ decides is given as:

$$
\text { Pollination Mode }= \begin{cases}\text { Global Pollination, } & r<p ; \\ \text { Local Pollination, } & \text { otherwise, }\end{cases}
$$

where $r \in[0,1]$.

The fitness evaluation of FPA is calculated as Fitness $=$ fit $(X)$,

where $X$ is an individual solution in the population, and the $t$ represents the abstract expression of the optimization problem. It is to be noted that for different optimization problems, the mathematical expressions could be different.

The flowchart of FPA is shown in Fig. 4.

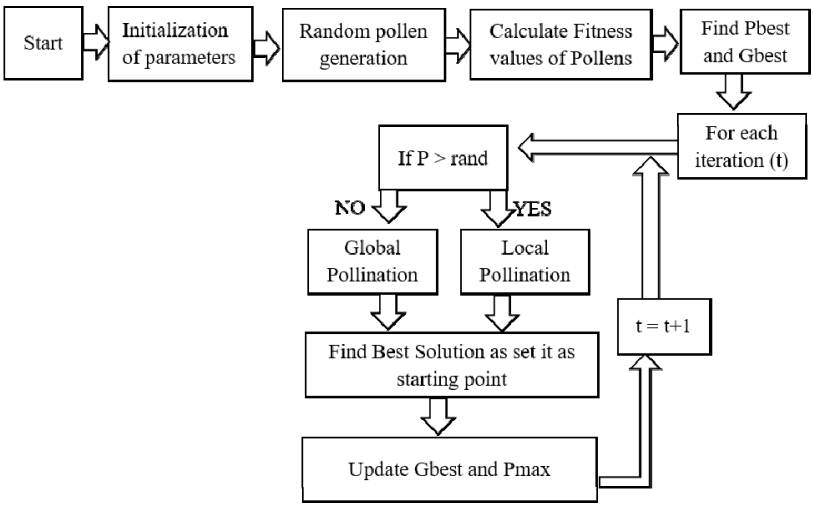

Fig. 4. Flowchart of FPA

4.2. Least square method. The LS method [33] is an important numerical method which is used to obtain a regression line or a line that best-suits for a provided pattern. It's defined with an equation that contains particular parameters. It's mostly utilized in evaluation and regression. When used in regression, known as a standard approach for the approximation of set of equations that contains more number of equations than the number of unknowns.

The LS in fact explains the solution for the minimization of the sum of squares of deviations or the errors in the result of each equation, and finds the formula for sum of squares of errors, which facilitates to look for the fluctuations and variations in observed or experimental data.

The LS is mostly utilized in data fitting. The result which best-fits is expected to reduce the sum of squared errors or residuals that are differences between the observed/experimental values, and corresponding fitted value given in the model.
4.2.1. Least square method graph. For linear regression, the straight line is a best fitting line, as shown in the Fig. 5.

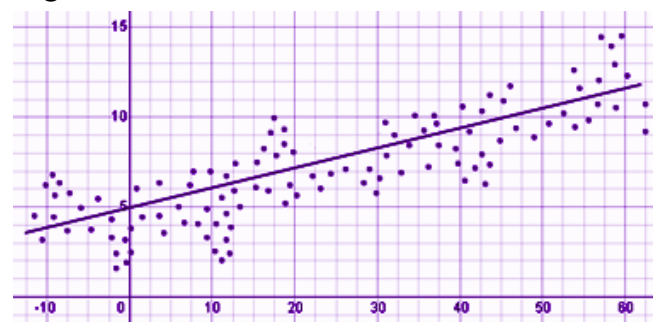

Fig. 5. Linear regression - line of best fit

The given data points are aimed to be minimized using the technique of reducing residuals or offsets of each data point from the straight line. Surface, polynomial, and hyperplane problems often use vertical offset. While in common practices, perpendicular offsets are utilized as shown in Fig. 6.
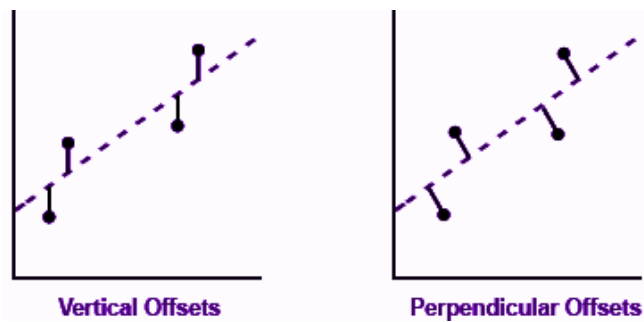

Fig. 6. Method of reducing offsets

5. Results and discussion. Two solar cell models are considered from [34], and are mentioned in Table 1, 2. Using values from tables, parameters are estimated using proposed technique and are compared with recently published research works to prove the efficiency.

Table 1

STM-640-36-Manufacturer's datasheet

\begin{tabular}{|c|c|}
\hline Datasheet parameters variables & STM-640-36 \\
\hline$P_{\max }, \mathrm{W}$ & 25.47 \\
\hline$V_{m p}, \mathrm{~V}$ & 16.98 \\
\hline$I_{m p}, \mathrm{~mA}$ & 1.50 \\
\hline$V_{o c}, \mathrm{~V}$ & 21.02 \\
\hline$I_{s c}, \mathrm{~mA}$ & 1.663 \\
\hline$S_{c s}, \mathrm{units}$ & 36 \\
\hline$T,{ }^{\circ} \mathrm{C}$ & 51 \\
\hline
\end{tabular}

Table 2

JP-270-M60-Manufacturer's datasheet

\begin{tabular}{|c|c|}
\hline Datasheet parameters variables & JP-270-M60 \\
\hline$P_{\max }, \mathrm{W}$ & 269.948 \\
\hline$V_{m p}, \mathrm{~V}$ & 31.10 \\
\hline$I_{m p}, \mathrm{~mA}$ & 8.68 \\
\hline$V_{o c}, \mathrm{~V}$ & 38.60 \\
\hline$I_{s c}, \mathrm{~mA}$ & 9.20 \\
\hline$S_{c s}$, units & 60 \\
\hline$T,{ }^{\circ} \mathrm{C}$ & 25 \\
\hline
\end{tabular}

5.1. Estimation of $P-V$ characteristic curve with LS, GA, LS hybrid with GA and proposed method is represented in Table 3, 4 . 
Estimated parameters of STM-640-36 with LS, GA, LS hybrid with GA and proposed method

\begin{tabular}{|c|c|c|c|c|c|}
\hline $\begin{array}{l}\text { Name } \\
\text { of the } \\
\text { solar } \\
\text { cell }\end{array}$ & $\begin{array}{l}\text { Parameters } \\
\text { to be } \\
\text { estimated }\end{array}$ & $\begin{array}{l}\text { Least } \\
\text { square } \\
(\mathrm{LS})\end{array}$ & $\begin{array}{l}\text { Genetic } \\
\text { algorithm } \\
\text { (GA) }\end{array}$ & $\begin{array}{c}\text { LS hybrid } \\
\text { with GA } \\
\text { [31] }\end{array}$ & $\begin{array}{l}\text { Proposed } \\
\text { method }\end{array}$ \\
\hline \multirow{6}{*}{ 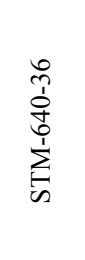 } & $I_{p h n}, \mathrm{~mA}$ & 1.6634 & 1.6637 & 1.664 & 1.6642 \\
\hline & $I_{d}, \mathrm{~mA}$ & $1.1225 \mathrm{e}^{-6}$ & $9.8541 \cdot 10^{-7}$ & $9.0122 \cdot 10^{-7}$ & $9.0081 \cdot 10^{-7}$ \\
\hline & $R_{s}, \Omega$ & 0.2704 & 0.23695 & 0.2254 & 0.235 \\
\hline & $R_{s h}, \Omega$ & 504.234 & 502.9223 & 488.2172 & 484 \\
\hline & $V_{d i}, \mathrm{~V}$ & 1.4891 & 1.4678 & 1.4582 & 2.356 \\
\hline & $A, \mathrm{~W}$ & - & - & 1.57636 & 1.5781 \\
\hline
\end{tabular}

Estimated parameters of JP-270-M60

Table 4 with LS, GA, LS hybrid with GA and proposed method

\begin{tabular}{|c|c|c|c|c|c|}
\hline $\begin{array}{l}\text { Name } \\
\text { of the } \\
\text { solar } \\
\text { cell }\end{array}$ & $\begin{array}{l}\text { Parameters } \\
\text { to be } \\
\text { estimated }\end{array}$ & $\begin{array}{c}\text { Least } \\
\text { square } \\
(\mathrm{LS})\end{array}$ & $\begin{array}{l}\text { Genetic } \\
\text { algorithm } \\
\text { (GA) }\end{array}$ & $\begin{array}{c}\text { LS hybrid } \\
\text { with GA } \\
\text { [31] }\end{array}$ & $\begin{array}{c}\text { Proposed } \\
\text { method }\end{array}$ \\
\hline \multirow{6}{*}{ 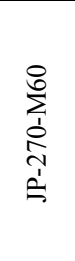 } & $I_{p h n}, \mathrm{~mA}$ & 9.1987 & 9.2005 & $9.19 / 4$ & 9.1976 \\
\hline & $I_{d}, \mathrm{~mA}$ & $1.0259 \cdot 10^{-9}$ & $1.1940 \cdot 10^{-9}$ & $1.0110 \cdot 10^{-9}$ & $1.013 \cdot 10^{-9}$ \\
\hline & $R_{s}, \Omega$ & 0.3142 & 0.30985 & 0.3043 & 0.09095 \\
\hline & $R_{s h}, \Omega$ & 9100.1 & 9137.8 & 9192.9 & 9198 \\
\hline & $V_{d i}, \mathrm{~V}$ & 1.6844 & 1.69706 & 1.684 & 2.3 \\
\hline & $A, \mathrm{~W}$ & - & - & 1.0906032 & 1.0307 \\
\hline
\end{tabular}

Using these results from Table 3,4 , the $P-V$ characteristics curve are obtained and are shown in Fig. 7-10.

It is clear from the $P-V$ curves that the proposed approach is much closer to the MPP as compared to the other contemporary methods. Evaluation of parameters show that more realistic curves are produced using the proposed method in comparison to other methods. So, it is conclude that the proposed method produces way better results as compared to contemporary methods.
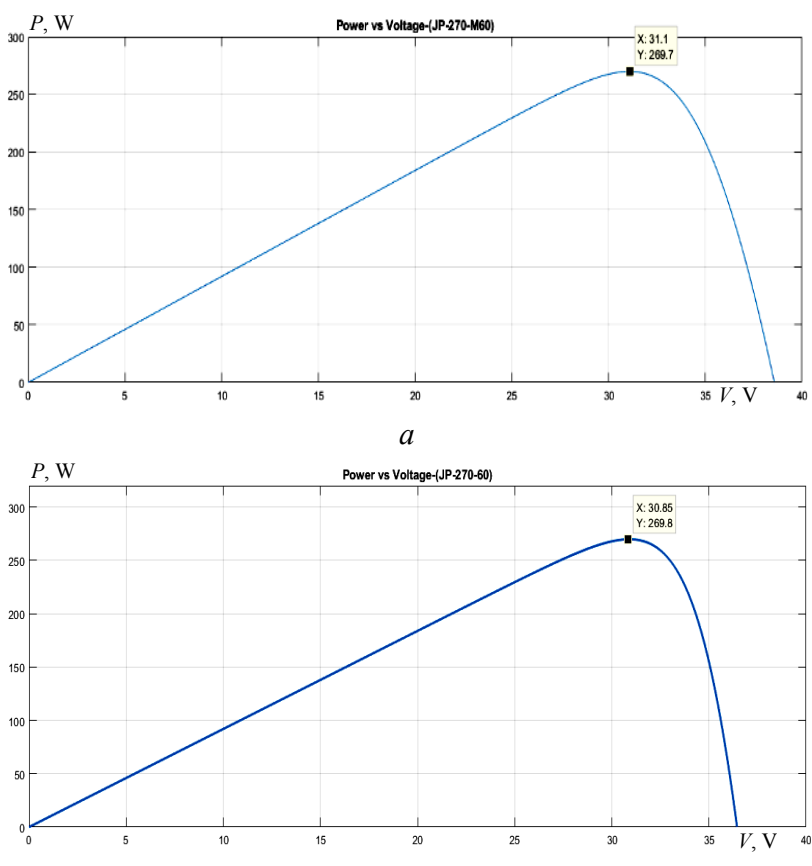

$b$

Fig. 7. Solar cell JP-270-M60:

(a) $P$ - $V$ curve of LS-GA; (b) $P-V$ curve of proposed method
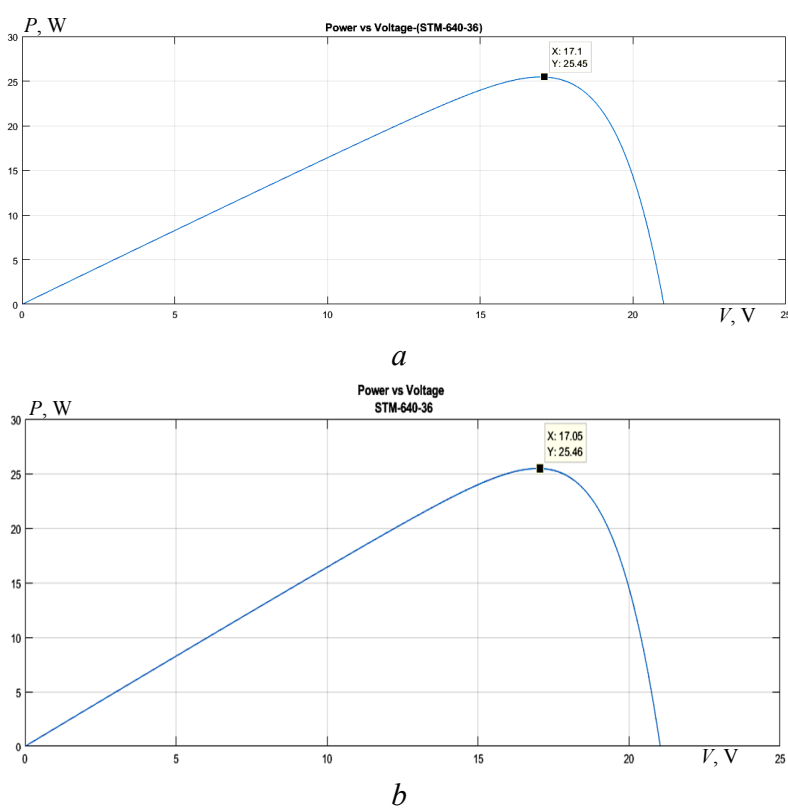

Fig. 8. Solar cell STM-640-36:

(a) $P$ - $V$ curve of LS-GA; (b) $P-V$ curve of proposed method

Figure 7 shows that out of JP-270-M60 of $270 \mathrm{~W}$, and LS-GA was able to extract $269.7 \mathrm{~W}$ of power where proposed approach succeeded to extract $269.8 \mathrm{~W}$ that surpasses the LS-GA proving it to be the better in terms of parameter extraction.

Figure 8 shows that out of STM-640-36 of $25.47 \mathrm{~W}$, and LS-GA extracted $25.45 \mathrm{~W}$ while proposed method extracted $25.46 \mathrm{~W}$.

Figures 9, 10 show the comparative analysis of both Fig. 7, 8 to prove the effectiveness of proposed scheme.

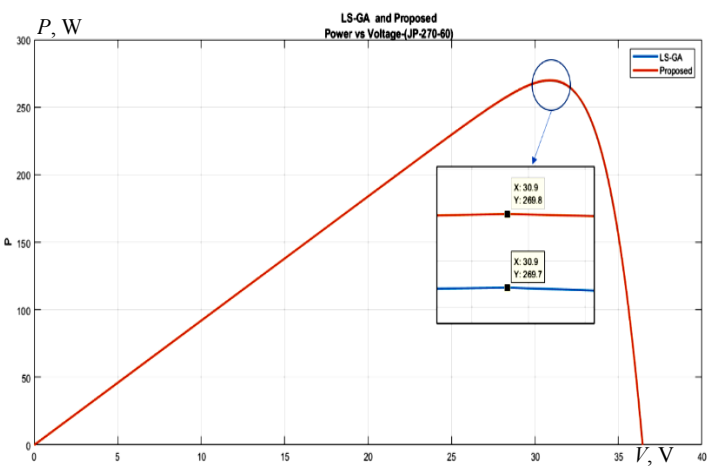

Fig. 9. JP-270-60 comparison between LS-GA and proposed method

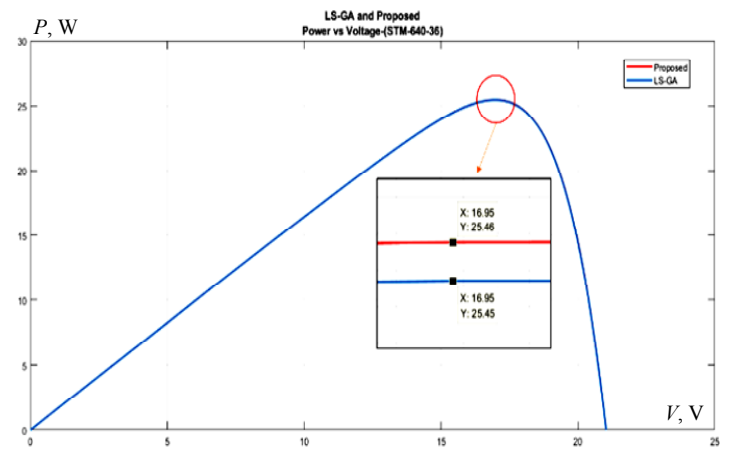

Fig. 10. STM-640-36 comparison between LS-GA and proposed method

5.2. Estimation of $P-V$ maximum power point error with proposed, SA and Newton-Raphson and 
least square method. MPPE is defined as the measured difference between the rated power $P_{\text {rated }}$ and the calculated power. This MPPE for different techniques have been summarized in Table 5. It is observed from Table 5 that the MPPE for the proposed method is least among all as compared to other methods.

Comparison of MPP, MPPE between LS, GA, LS-GA and proposed method

\begin{tabular}{|c|c|c|c|}
\hline Parameter & Methods & JP-270-M60 & STM-640-36 \\
\hline$P_{\text {rated }}, \mathrm{W}$ & & 269.948 & 25.47 \\
\hline \multirow{3}{*}{$P_{\text {mpp }}, \mathrm{W}$} & LS & 269.4701 & 25.4251 \\
\cline { 2 - 4 } & GA & 269.6605 & 25.4391 \\
\cline { 2 - 4 } & LS-GA & 269.7208 & 25.4585 \\
\cline { 2 - 4 } & Proposed & 269.8 & 25.46 \\
\hline \multirow{3}{*}{ MPPE } & LS & 0.17703 & 0.17628 \\
\cline { 2 - 4 } & GA & 0.10650 & 0.12131 \\
\cline { 2 - 4 } & LS-GA & 0.08416 & 0.04515 \\
\cline { 2 - 4 } & Proposed & 0.0548 & 0.000392 \\
\hline
\end{tabular}

\section{Conclusions.}

In this paper, characteristic equation in terms series resistance and diode-ideality factor are derived. Flower pollination algorithm is utilized on characteristic equation to estimate series resistance and diode-ideality factor. Least square method is utilized to estimate the remaining parameters such as shunt-resistance, photon-current, and diode dark saturation current. For the purpose of simulations and validations, 2 different solar cell models are considered. $P-V$ curves and maximum power point error are calculated using proposed technique. Solar panel of $270 \mathrm{~W}$, hybrid least square and genetic algorithm was able to extract $269.7 \mathrm{~W}$ of power where proposed approach succeeded to extract $269.8 \mathrm{~W}$ that surpasses the hybrid least square and genetic algorithm proving it to be the better in terms of parameter extraction. Shunt and series resistances are considered and are not neglected in this approach that previously has been in practice. Also the number of equations is reduced that brings the edge of less computation burden. This will help producers and consumers in acquiring efficient solar panels that will increase electricity output and better revenue. This research for solar cell/panel can be utilized in energy storage system of distribution static compensator to efficiently improve the power quality in distribution system.

Conflict of interest. The authors declare that they have no conflicts of interest.

\section{REFERENCES}

1. Ullah M.F., Hanif A. Power quality improvement in distribution system using distribution static compensator with super twisting sliding mode control. International Transactions on Electrical Energy Systems, 2021, vol. 31, no. 9, art. no. e12997 doi: https://doi.org/10.1002/2050-7038.12997.

2. Anwar N., Hanif A.H., Khan H.F., Ullah M.F. Transient stability analysis of the IEEE-9 bus system under multiple contingencies. Engineering, Technology \& Applied Science Research, 2020, vol. 10, no. 4, pp. 5925-5932. doi: https://doi.org/10.48084/etasr.3273.

3. Mehdi M.F., Ahmad A., Ul Haq S.S., Saqib M., Ullah M.F. Dynamic economic emission dispatch using whale optimization algorithm for multi-objective function. Electrical Engineering \& Electromechanics, 2021, no. 2, pp.
https://doi.org/10.20998/2074-272x.2021.2.09.

64-69. doi:

4. Ahmed W., Sheikh J.A., Ahmad S., Farjana S.H., Mahmud M.A.P. Impact of PV system orientation angle accuracy on greenhouse gases mitigation. Case Studies in Thermal Engineering, 2021, vol. 23, p. 100815. doi: https://doi.org/10.1016/j.csite.2020.100815.

5. Ahmed W., Sheikh J.A., Kouzani A.Z., Mahmud M.A.P. The Role of single end-users and producers on GHG mitigation in Pakistan - a case study. Sustainability, 2020, vol. 12, no. 20, p. 8351. doi: https://doi.org/10.3390/su12208351.

6. Shongwe S., Hanif M. Comparative analysis of different single-diode PV modeling methods. IEEE Journal of Photovoltaics, 2015, vol. 5, no. 3, pp. 938-946. doi: https://doi.org/10.1109/jphotov.2015.2395137.

7. Sarquis Filho E.A., Fernandes C.A.F., Da Costa Branco P.J. A complete framework for the simulation of photovoltaic arrays under mismatch conditions. Solar Energy, 2021, vol. 213, pp. 13-26. doi: https://doi.org/10.1016/j.solener.2020.10.055.

8. Appelbaum J., Peled A. Parameters extraction of solar cells - a comparative examination of three methods. Solar Energy Materials and Solar Cells, 2014, vol. 122, pp. 164-173. doi: https://doi.org/10.1016/j.solmat.2013.11.011.

9. Yetayew T.T., Jyothsna T.R. Parameter extraction of photovoltaic modules using Newton Raphson and simulated annealing techniques. 2015 IEEE Power, Communication and Information Technology Conference (PCITC), 2015, pp. 229234. doi: https://doi.org/10.1109/pcitc.2015.7438166.

10. Shongwe S., Hanif M. Gauss-Seidel iteration based parameter estimation for a single diode model of a PV module. 2015 IEEE Electrical Power and Energy Conference (EPEC), 2015, pp. 278284. doi: https://doi.org/10.1109/EPEC.2015.7379963.

11. Chatterjee A., Keyhani A., Kapoor D. Identification of photovoltaic source models. IEEE Transactions on Energy Conversion, 2011, vol. 26, no. 3, pp. 883-889. doi: https://doi.org/10.1109/TEC.2011.2159268.

12. Uoya M., Koizumi H. A calculation method of photovoltaic array's operating point for MPPT evaluation based on onedimensional Newton-Raphson method. IEEE Transactions on Industry Applications, 2015, vol. 51, no. 1, pp. 567-575. doi: https://doi.org/10.1109/tia.2014.2326083.

13. Accarino J., Petrone G., Ramos-Paja C.A., Spagnuolo G. Symbolic algebra for the calculation of the series and parallel resistances in PV module model. 2013 International Conference on Clean Electrical Power (ICCEP), 2013, pp. 62-66. doi: https://doi.org/10.1109/ICCEP.2013.6586967.

14. Huang P., Xiao W., Peng J.C.-H., Kirtley J.L. Comprehensive parameterization of solar cell: improved accuracy with simulation efficiency. IEEE Transactions on Industrial Electronics, 2016, vol. 63, no. 3, pp. 1549-1560. doi: https://doi.org/10.1109/TIE.2015.2498139.

15. Shahzad A., Lee M., Lee Y.-K., Kim S., Xiong N., Choi J.Y., Cho Y. Real time MODBUS transmissions and cryptography security designs and enhancements of protocol sensitive information. Symmetry, 2015, vol. 7, no. 3, pp. 1176-1210. doi: https://doi.org/10.3390/sym7031176.

16. Zhang Q., Zhou C., Xiong N., Qin Y., Li X., Huang S. Multimodel-based incident prediction and risk assessment in dynamic cybersecurity protection for industrial control systems. IEEE Transactions on Systems, Man, and Cybernetics: Systems, 2016, vol. 46, no. 10, pp. 1429-1444. doi: https://doi.org/10.1109/TSMC.2015.2503399.

17. Huang K., Zhang Q., Zhou C., Xiong N., Qin Y. An efficient intrusion detection approach for visual sensor networks based on traffic pattern learning. IEEE Transactions on Systems, Man, and Cybernetics: Systems, 2017, vol. 47, no. 10, pp. 27042713. doi: https://doi.org/10.1109/TSMC.2017.2698457.

18. Zagrouba M., Sellami A., Bouaïcha M., Ksouri M. Identification of PV solar cells and modules parameters using 
the genetic algorithms: Application to maximum power extraction. Solar Energy, 2010, vol. 84, no. 5, pp. 860-866. doi: https://doi.org/10.1016/j.solener.2010.02.012.

19. Ye M., Wang X., Xu Y. Parameter extraction of solar cells using particle swarm optimization. Journal of Applied Physics, 2009, vol. 105, no. 9, p. 094502. doi: https://doi.org/10.1063/1.3122082.

20. Khanna V., Das B.K., Bisht D., Vandana, Singh P.K. A three diode model for industrial solar cells and estimation of solar cell parameters using PSO algorithm. Renewable Energy, 2015, vol. 78, pp. 105-113. doi: https://doi.org/10.1016/j.renene.2014.12.072.

21. El-Naggar K.M., AlRashidi M.R., AlHajri M.F., Al-Othman A.K. Simulated Annealing algorithm for photovoltaic parameters identification. Solar Energy, 2012, vol. 86, no. 1, pp. 266-274. doi: https://doi.org/10.1016/j.solener.2011.09.032.

22. Jiang L.L., Maskell D.L., Patra J.C. Parameter estimation of solar cells and modules using an improved adaptive differential evolution algorithm. Applied Energy, 2013, vol. 112, pp. 185193. doi: https://doi.org/10.1016/j.apenergy.2013.06.004.

23. Patel S.J., Panchal A.K., Kheraj V. Extraction of solar cell parameters from a single current-voltage characteristic using teaching learning based optimization algorithm. Applied Energy, 2014, vol. 119, pp. 384-393. doi https://doi.org/10.1016/j.apenergy.2014.01.027.

24. Celik A.N., Acikgoz N. Modelling and experimental verification of the operating current of mono-crystalline photovoltaic modules using four- and five-parameter models Applied Energy, 2007, vol. 84, no. 1, pp. 1-15. doi: https://doi.org/10.1016/j.apenergy.2006.04.007.

25. Vijayakumari A., Devarajan A.T., Devarajan N. Design and development of a model-based hardware simulator for photovoltaic array. International Journal of Electrical Power \& Energy Systems, 2012, vol. 43, no. 1, pp. 40-46. doi: https://doi.org/10.1016/j.ijepes.2012.04.049.

26. Tan Y.T., Kirschen D.S., Jenkins N. A model of PV generation suitable for stability analysis. IEEE Transactions on Energy Conversion, 2004, vol. 19, no. 4, pp. 748-755. doi: https://doi.org/10.1109/tec.2004.827707.

27. Benavides N.D., Chapman P.L. Modeling the effect of voltage ripple on the power output of photovoltaic modules. IEEE Transactions on Industrial Electronics, 2008, vol. 55, no. 7, pp. 2638-2643. doi: https://doi.org/10.1109/TIE.2008.921442. 28. Bharadwaj P., Chaudhury K.N., John V. Sequential optimization for PV panel parameter estimation. IEEE Journal of Photovoltaics, 2016, vol. 6, no. 5, pp. 1261-1268. doi: https://doi.org/10.1109/JPHOTOV.2016.2574128.

29. De Soto W., Klein S.A., Beckman W.A. Improvement and validation of a model for photovoltaic array performance. Solar Energy, 2006, vol. 80, no. 1, pp. 78-88. doi: http://dx.doi.org/10.1016/j.solener.2005.06.010.
30. Xiao W., Edwin F.F., Spagnuolo G., Jatskevich J. Efficient approaches for modeling and simulating photovoltaic power systems. IEEE Journal of Photovoltaics, 2013, vol. 3, no. 1, pp. 500-508. doi: https://doi.org/10.1109/JPHOTOV.2012.2226435. 31. Silva E.A., Bradaschia F., Cavalcanti M.C., Nascimento A.J. Parameter estimation method to improve the accuracy of photovoltaic electrical model. IEEE Journal of Photovoltaics, 2016, vol. 6, no. 1, pp. 278-285. doi: https://doi.org/10.1109/JPHOTOV.2015.2483369.

32. Yang X.-S. Flower Pollination Algorithm for Global Optimization. In: Durand-Lose J., Jonoska N. (eds) Unconventional Computation and Natural Computation. UCNC 2012. Lecture Notes in Computer Science, vol. 7445. Springer, Berlin, Heidelberg. doi: https://doi.org/10.1007/978-3-64232894-7 27.

33. Nayak B.K., Mohapatra A., Mohanty K.B. Parameters estimation of photovoltaic module using nonlinear least square algorithm: A comparative study. 2013 Annual IEEE India Conference (INDICON), 2013, pp. 1-6. doi: https://doi.org/10.1109/INDCON.2013.6726120.

34. Tong N.T., Pora W. A parameter extraction technique exploiting intrinsic properties of solar cells. Applied Energy, 2016, vol. 176, pp. 104-115. doi: https://doi.org/10.1016/j.apenergy.2016.05.064.

35. Zain-Ul-Abdin, Mahmood T., Shorfuzzaman M., Xiong N.N., Mehmood R.M. Aiding prosumers by solar cell parameter optimization using a hybrid technique for achieving near realistic $\mathrm{P}-\mathrm{V}$ characteristics. IEEE Access, 2020, vol. 8, pp. 225416225423. doi: https://doi.org/10.1109/ACCESS.2020.3043941.

Received 25.07.2021

Accepted 30.10.2021

Published 03.12.2021

Faizan Akbar ${ }^{1}, M S$,

Tahir Mahmood ${ }^{1}$, Professor

Kamran Sadiq ${ }^{1}, M S$,

Mian Farhan Ullah ${ }^{2}$, PhD Scholar, Lecturer,

${ }^{1}$ Department of Electrical Engineering,

University of Engineering and Technology, Taxila, Pakistan,

e-mail: engr.faizanakbar@gmail.com,

tahir.mehmood@uettaxila.edu.pk,

kamransadiqawan@gmail.com

${ }^{2}$ Department of Mechatronics Engineering,

Wah Engineering College, University of Wah,

Quaid Avenue, Wah Cantt, Rawalpindi District,

Punjab 47040, Pakistan,

e-mail: farhan.ullah@wecuw.edu.pk (Corresponding author)

How to cite this article:

Akbar F., Mehmood T., Sadiq K., Ullah M.F. Optimization of accurate estimation of single diode solar photovoltaic parameters and extraction of maximum power point under different conditions. Electrical Engineering \& Electromechanics, 2021, no. 6, pp. 46-53. doi: https://doi.org/10.20998/2074-272X.2021.6.07. 